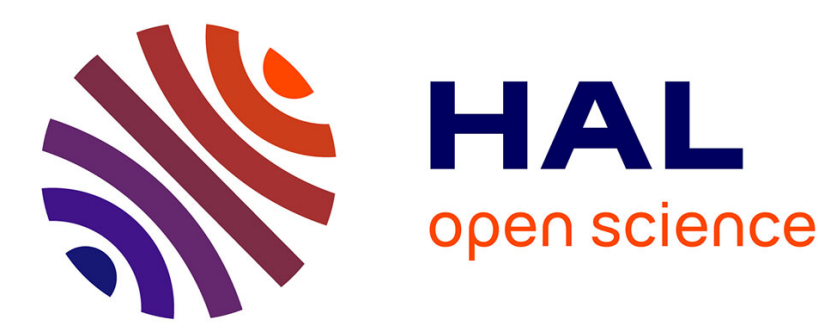

\title{
Friction losses and heat transfer of single-phase flow in a mini-channel
}

\author{
Nadia Caney, Philippe Marty, Jérôme Bigot
}

\section{To cite this version:}

Nadia Caney, Philippe Marty, Jérôme Bigot. Friction losses and heat transfer of singlephase flow in a mini-channel. Applied Thermal Engineering, 2007, 27, pp.1715-1721. 10.1016/j.applthermaleng.2006.07.019 . hal-00266660

\section{HAL Id: hal-00266660 \\ https://hal.science/hal-00266660}

Submitted on 18 Feb 2020

HAL is a multi-disciplinary open access archive for the deposit and dissemination of scientific research documents, whether they are published or not. The documents may come from teaching and research institutions in France or abroad, or from public or private research centers.
L'archive ouverte pluridisciplinaire HAL, est destinée au dépôt et à la diffusion de documents scientifiques de niveau recherche, publiés ou non, émanant des établissements d'enseignement et de recherche français ou étrangers, des laboratoires publics ou privés. 


\title{
Friction losses and heat transfer of single-phase flow in a mini-channel
}

\author{
N. Caney *, P. Marty, J. Bigot \\ LEGI-GREThE, CEA Grenoble, 17, rue des martyrs 38054 Grenoble Cedex 9, France
}

\begin{abstract}
Experimental frictional pressure drop and heat transfer during single phase flow in a vertical mini-channel have been studied with the aim of determining the validity of classical correlations available for conventional size channels. A $1 \mathrm{~mm}$ square channel etched in a $420 \mathrm{~mm}$ long test section of aluminum has been investigated. The Reynolds number has been varied from 310 to 7780 in order to cover the laminar regime as well as the beginning of the turbulent regime. The heat flux supplied to the fluid varies from $1 \mathrm{~kW} / \mathrm{m}^{2}$ to $8 \mathrm{~kW} / \mathrm{m}^{2}$. Experimental frictional pressure drop measurements show that classical correlations accurately apply. Temperature measurements along the channel show that the temperature profile is drastically different from the expected linear behaviour owing to an important longitudinal heat flux in the channel wall. This heat flux mal-distribution which has been recently discussed in the literature is clearly shown and studied in more details by a numerical simulation of the experiment. This numerical work has allowed to make a correction on temperature measurements. Once corrected, the heat transfer measurements are in fair agreement with the classical literature results.
\end{abstract}

Keywords: Mini-channel; Pressure drop; Heat transfer

\section{Introduction}

The development of new applications needing the cooling of components in a confined space has motivated recent studies aiming at predicting the fluid flow in mini- and micro-channels. ${ }^{1}$ Surprisingly, the frictional pressure losses measurements reported in the literature do not agree each other although accurate techniques have been used in the small size channels which have been investigated. More surprising is the tendency which is often reported to depart from conventional channels behaviour. In a recent paper, Brutin [4] reviews different studies in mini-channels and concludes that classical predictions fail when an ionic working fluid is used in association with an electrically insulated wall. This raises the question of the electrical con-

\footnotetext{
* Corresponding author. Tel.: +334387894 22; fax: +3343878 5172 . E-mail address: nadia.caney@cea.fr (N. Caney).

${ }^{1}$ The classification proposed by Kandlikar and Grande [8] is used: conventional channels $\left(D_{\mathrm{h}}>3 \mathrm{~mm}\right)$, mini-channels $\left(200 \mu \mathrm{m}<D_{\mathrm{h}}<\right.$ $3 \mathrm{~mm})$, and micro-channels $\left(D_{\mathrm{h}}<200 \mu \mathrm{m}\right)$.
}

ductivity of the fluid and of its influence on the pressure drop. More recently, Bavière et al. [2] investigate water circulation in a $7.5 \mu \mathrm{m} \times 3 \mathrm{~mm}$ single flat channel made of Pyrex. As expected, the authors find the classical value of 96 for the Poiseuille number. Phares and Smedley [12] report similar results from experimentations done in a series of short microtubes ranging from 80 to $150 \mu \mathrm{m}$. Gao et al. [6] investigate water circulation in a channel having an hydraulic diameter ranging from $200 \mu \mathrm{m}$ to $1923 \mu \mathrm{m}$ and also obtain a good agreement between their results and those of conventional channels. Fig. 1 shows their friction measurements as a function of the Reynolds number for different hydraulic diameters. Both Shah and London [13] and Blasius [3] correlations suitably predict their experimental results for laminar and turbulent regimes, respectively.

A study of the influence of the experimental uncertainties shows a considerable importance of the precise knowledge of the hydraulic diameter. An inaccurate evaluation of this quantity can lead to a huge error in the friction factor calculation. This point is confirmed by Agostini [1] who 


\section{Nomenclature}

$\begin{array}{ll}c_{p} & \text { specific heat of the fluid }\left[\mathrm{J} \mathrm{kg}^{-1} \mathrm{~K}^{-1}\right] \\ D_{\mathrm{h}} & \text { hydraulic diameter [m] } \\ e_{\mathrm{w}} & \text { wall thickness [m] } \\ f & \text { friction factor [m] } \\ g & \left.\text { gravity [m s }{ }^{-2}\right] \\ h & \text { channel height [m] } \\ l & \text { channel width [m] } \\ L & \text { channel length [m] } \\ L_{\mathrm{t}} & \text { thermal length [m] } \\ \dot{m} & \text { mass flow rate }\left[\mathrm{kg} \mathrm{s}^{-1}\right] \\ P & \text { pressure }[\mathrm{Pa}] \\ P o & \text { Poiseuille number } P o=4 f \operatorname{Re}[-] \\ P r & \text { Prandtl number } \operatorname{Pr}=\frac{\mu c_{p}}{\lambda}[-] \\ R e & \text { Reynolds number } \operatorname{Re}=\frac{\rho U D_{\mathrm{h}}}{\mu}[-] \\ U & \left.\text { velocity [m s }{ }^{-1}\right]\end{array}$

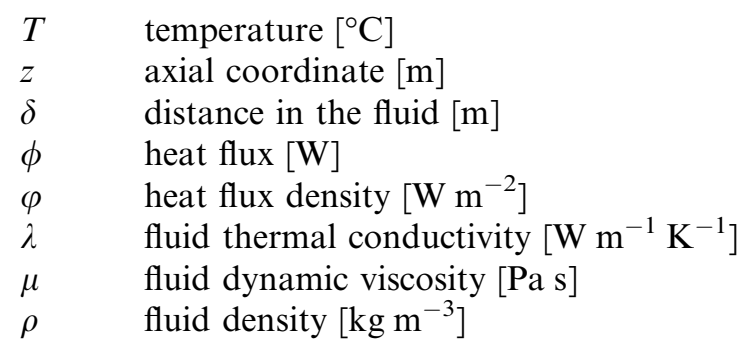

$\begin{array}{ll}\text { Indices } & \\ \exp & \text { experimental } \\ \text { th } & \text { theoretical } \\ \mathrm{w} & \text { wall } \\ \mathrm{f} & \text { fluid }\end{array}$

$$
\begin{aligned}
+\mathrm{e} & =1 \mathrm{~mm} \\
* \mathrm{e} & =0.7 \mathrm{~mm} \\
\bullet & \mathrm{e}=0.5 \mathrm{~mm} \\
-\mathrm{e} & =0.4 \mathrm{~mm} \\
\triangle \mathrm{e} & =0.3 \mathrm{~mm} \\
\mathrm{Oe} & =0.2 \mathrm{~mm} \\
\square \mathrm{e} & =0.1 \mathrm{~mm}
\end{aligned}
$$

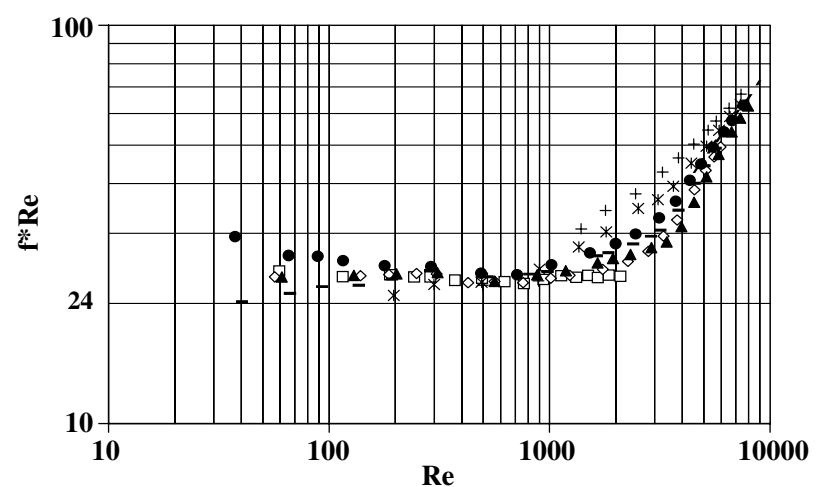

Fig. 1. Evolution of the Poiseuille number ( $4 f R e$ ) with $R e$ for various channel dimensions in Gao et al. [6] study.

shows that friction factor value is strongly influenced by the channel dimensions uncertainties. Considering Fig. 2 [10] allows to illustrate the current dispersion between the experimental results from many authors. This figure shows how careful we should be when considering an apparently simple situation such as a laminar flow in a straight channel.

Concerning the literature on heat transfer measurements in small size channels, heat transfer coefficients seem either higher or lower than classical heat transfer correlations. The deviations from classical heat transfer coefficients may be justified by errors in the measurement of channels dimensions or uncertainties in the temperature recordings. However, no experimental study investigates the exact influence of the measurement method. In order to yield accurate heat transfer coefficients, at least two questions should be addressed. The first one is the method of measurement of the wall temperature: many authors use thermocouples imbedded in the wall in the vicinity of the interface between the solid and the fluid and have access to the interface temperature by performing an interpola- tion of the thermocouples values. A second question is worth of interest: does the heat flux homogeneously distribute in the channel? Maranzana et al. [9] compare longitudinal conduction heat flux along the channel walls to the flux which is conveyed by convection by the fluid (cf. Fig. 3). They introduce a parameter $M$ defined as following:

$M=\frac{\lambda_{\mathrm{w}} \frac{e_{\mathrm{w}}}{L}}{\rho c_{p} h U}$

which $M$ is the ratio of the resistance that the channel walls offer to the axial heat flux to the convective resistance. $\lambda_{\mathrm{w}}$ and $e_{\mathrm{w}}$ are the wall conductivity and the wall thickness respectively, and $L$ is the channel length (equal to $420 \mathrm{~mm}$ in the present study). $h$ is the fluid thickness and $U$ its velocity. The results of their analytical treatment show that the axial heat flux becomes significant when the parameter $M$ becomes greater than 0.01 . For values of $M$ greater than 0.05 , the fluid temperature distribution ceases to have a linear evolution along the channel axis.

As a contribution to this lack of clarity this paper reports a study on the frictional pressure drops and heat 


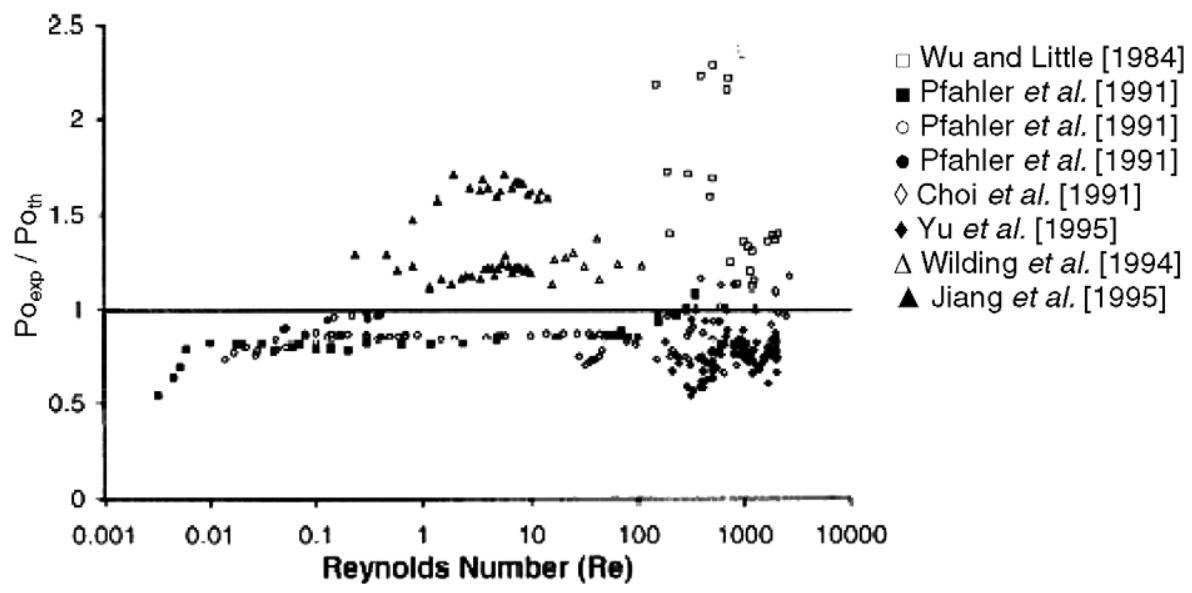

Fig. 2. Experimental Poiseuille numbers (4fRe) published in the literature $[5,7,11,14-16]$ as a function of the Reynolds number (after [10]).

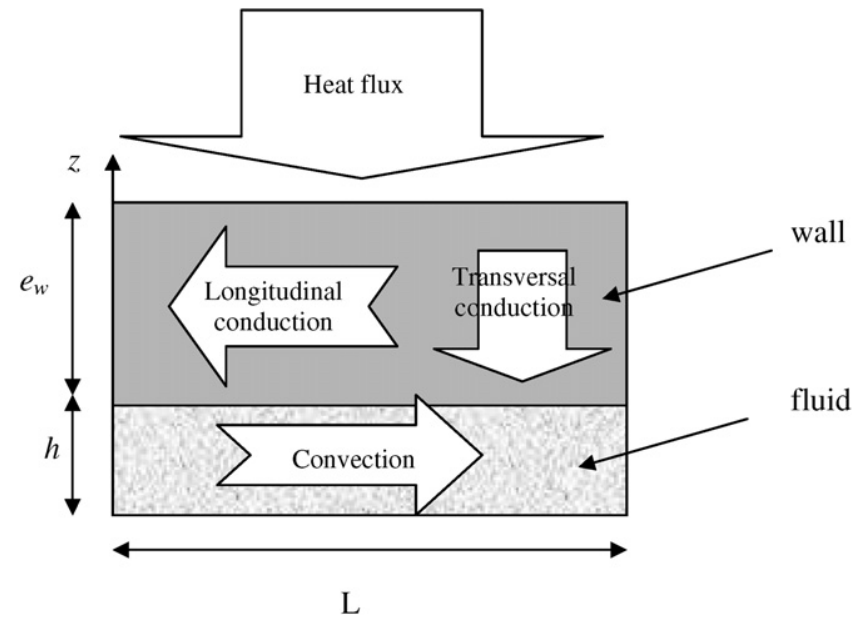

Fig. 3. Heat fluxes distribution in a $2 \mathrm{D}$ channel (after [9]).

transfer in a vertical mini-channel. In the first part, the frictional pressure drop is studied in order to check the validity of classical correlations. In the second part, the measurement of the heat transfer coefficients exemplifies the difficulty of working in a confined channel.

The present results will be compared to those obtained with a simple numerical modelling of one experiment: this will allow to provide some future recommendations concerning measurement and heat flux distribution in confined spaces.

\section{Experimental apparatus}

Fig. 4 shows the experimental set up. The test section consists of a vertical $15 \mathrm{~mm}$ thick aluminium plate (dimension $80 \times 500 \mathrm{~mm}$ ) in which a $1 \times 1 \mathrm{~mm}$ rectilinear channel has been machined. Details about this channel are shown in Fig. 5. The liquid enters at the bottom of the test section through a hole which is drilled perpendicularly to the aluminium plate. After a $90^{\circ}$ bend, the fluid flows vertically and is permanently heated all along its circulation into the channel. The fluid is heated to control the temperature

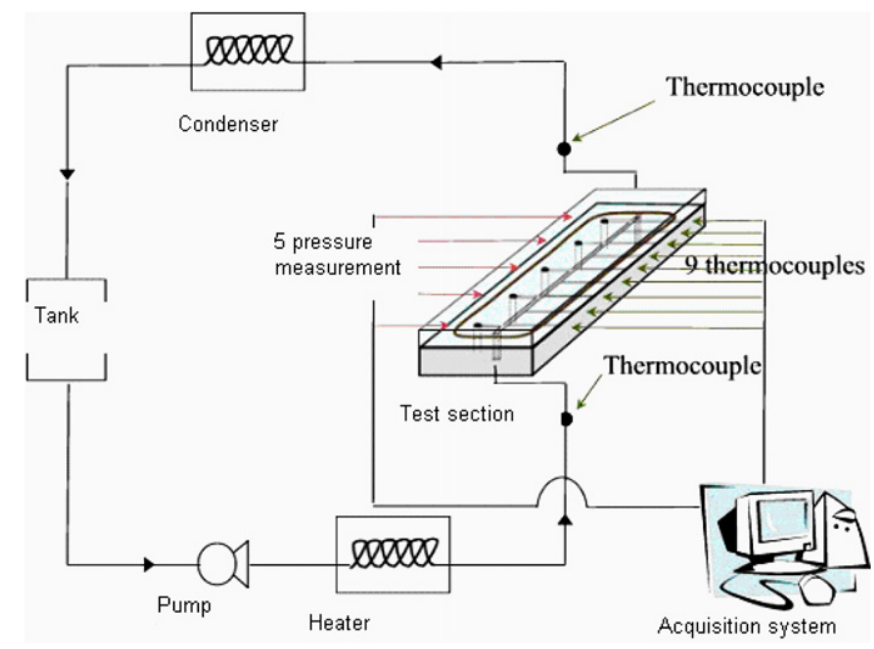

Fig. 4. Schematic of the experimental loop.

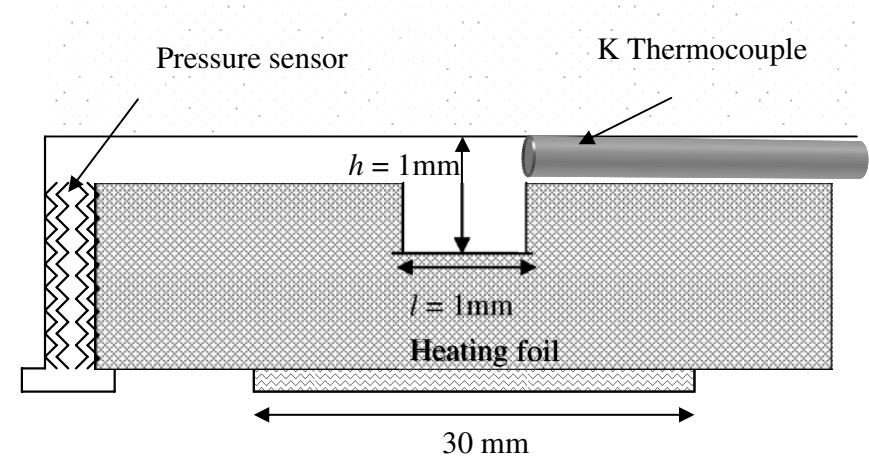

Fig. 5. Cross-sectional view of the test section showing the grooves in which thermocouples are inserted. The same technique is used to ensure fluid communication with the pressure transducers.

at the entrance of the test section. The temperature of the fluid at the inlet and outlet is measured with a platinum sensor. A heating resistive foil is glued onto the back side of the aluminium plate. It delivers a heat flux up to $75 \mathrm{~W}$. Every $50 \mathrm{~mm}, 9$ type-K thermocouples (external 
Table 1

Range and precision of experimental data (a) and channel dimension measurements (b)

\begin{tabular}{lllc}
\hline $\begin{array}{l}\text { Physical } \\
\text { quantity }\end{array}$ & Device & Range & Precision \\
\hline $\begin{array}{l}\text { Panel }(a) \\
\begin{array}{l}\text { Fluid } \\
\text { temperature }\end{array}\end{array}$ & $\begin{array}{l}\text { K Thermocouple diameter } \\
0.25 \mathrm{~mm}\end{array}$ & $20-80{ }^{\circ} \mathrm{C}$ & $0.2{ }^{\circ} \mathrm{C}$ \\
$\begin{array}{l}\text { Pressure } \\
\text { Flow rate }\end{array}$ & $\begin{array}{l}\text { Pressure sensor } \\
\text { Coriolis flowmeter }\end{array}$ & $0-1.7 \mathrm{bar}$ & $1.3 \mathrm{mbar}$ \\
& & $0-5 \mathrm{~kg} / \mathrm{h}$ & $0.42 \%$ \\
Panel $(b)$ & & Channel height $(\mathrm{mm})$ \\
Sensor & & $1.014 \pm 0.001$ \\
Lens & & $1.023 \pm 0.02$ \\
Microscope & & $1.004 \pm 0.013$ \\
\hline
\end{tabular}

Table 2

Experimental conditions

\begin{tabular}{ll}
\hline$\dot{m}\left(\mathrm{~kg} \mathrm{~s}^{-1}\right)$ & $2 \times 10^{-4}-4.9 \times 10^{-3}$ \\
$\operatorname{Re}$ & $310-7780$ \\
$P r$ & 7.3 \\
Room temperature $\left({ }^{\circ} \mathrm{C}\right)$ & 20 \\
$P(\mathrm{~Pa})$ & $10^{5}$ \\
\hline
\end{tabular}

diameter $0.25 \mathrm{~mm}$ ) are inserted in a $0.3 \mathrm{~mm}$ deep groove. As shown in Fig. 5 the tip of each thermocouple is located at the wall-fluid interface. This technique avoids using the classical technique described in the introduction and which consists in drilling small diameter holes in the aluminium plate. As it will be discussed in the next section, this measurement technique, although technically more simple, raises the following question: what is the significance of the temperature which is really measured? Is it representative of the wall temperature or, despite its location at the fluid interface, is it strongly influenced by the fluid temperature?

Concerning the fluid temperature in the core, its value is determined by an energy balance between the inlet and the position considered. The pressure profile along the channel is measured by five pressure transducers communicating with the channel through grooves located every $100 \mathrm{~mm}$. A coriolis-type flow meter measures the mass flow rate of the fluid downstream of the pump. Reynolds numbers range from 310 to 7780 . Channel dimensions have been carefully measured with three devices: a sensor, a lens and a microscope. Details about the experimental conditions and the uncertainties of the measurements are presented in Tables 1 and 2.

\section{Friction factor measurements}

The friction factor is experimentally investigated with the conditions summarised in Tables 1 and 2. The range of Reynolds number extends from laminar regime to the onset of turbulence. Owing to its wide industrial interest

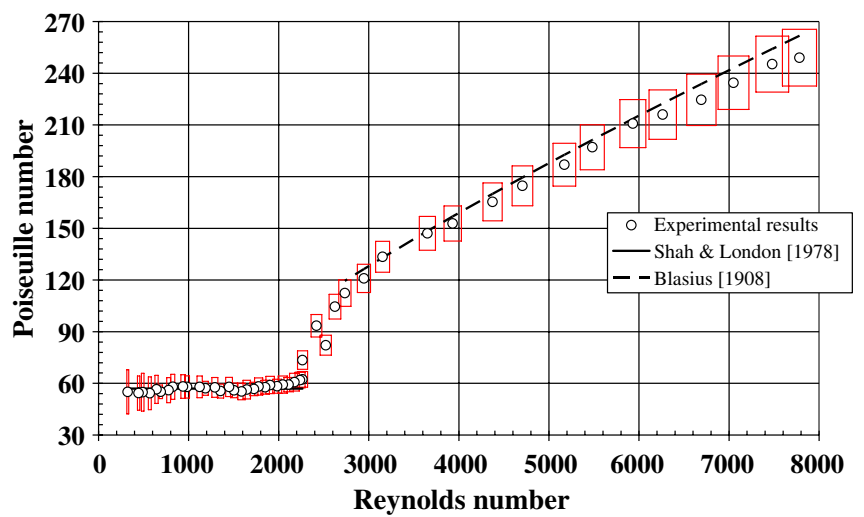

Fig. 6. Experimental Poiseuille number vs. the Reynolds number (rectangular windows show the uncertainties on the measurement).

(for example in the cooling of hydrogen fuel cells), much attention has been paid to the laminar regime.

For each value of the Reynolds number and of the heat flux, an averaged value of the friction factor is deduced from the slope of the pressure profile $\frac{\partial P}{\partial z}$, which includes viscous effects as well as gravity. One finds

$f=\frac{\frac{\partial P}{\partial z}-\rho g}{\frac{2 \rho U^{2}}{D_{\mathrm{h}}}}$

what can be expressed as a function of the mean flow rate and channel dimensions as

$f=\left(\frac{\partial P}{\partial z}-\rho g\right) \frac{\left(\dot{m}^{2}(l+h)\right)}{(l h)^{3} \rho}$

A time averaging method is used in order to reduce violent unsteady pressure oscillations. The results are expressed as a function of the Poiseuille number, $P o=4 f R e$, (cf. Fig. 6).

Shah and London [13] and Blasius [3] correlations suitably correlate the present experimental results. The transition from laminar to turbulent flow occurs around a Reynolds number equal to 2500. Effectively, for the laminar regime, the experimental Poiseuille number mean value is equal to 57 which is exactly the value given by Shah and London [13] correlation. The Reynolds and Poiseuille number uncertainties are estimated between $2.4-3.4 \%$ and between $6.6-23 \%$, respectively. The larger uncertainties correspond to measurements made in the transition zone. As a conclusion, we can see that the present friction factor results for a $1 \mathrm{~mm}$ channel seem in fair agreement with conventional channels correlations.

\section{Heat transfer results}

The heat transfer coefficient is classically deduced from the following expression:

$\alpha=\frac{\varphi}{T_{\mathrm{w}}-T_{\mathrm{f}}}$

$\varphi$ is the local heat flux density, $T_{\mathrm{w}}$ the wall temperature at the fluid-solid interface and $T_{\mathrm{f}}$ is the temperature in the 

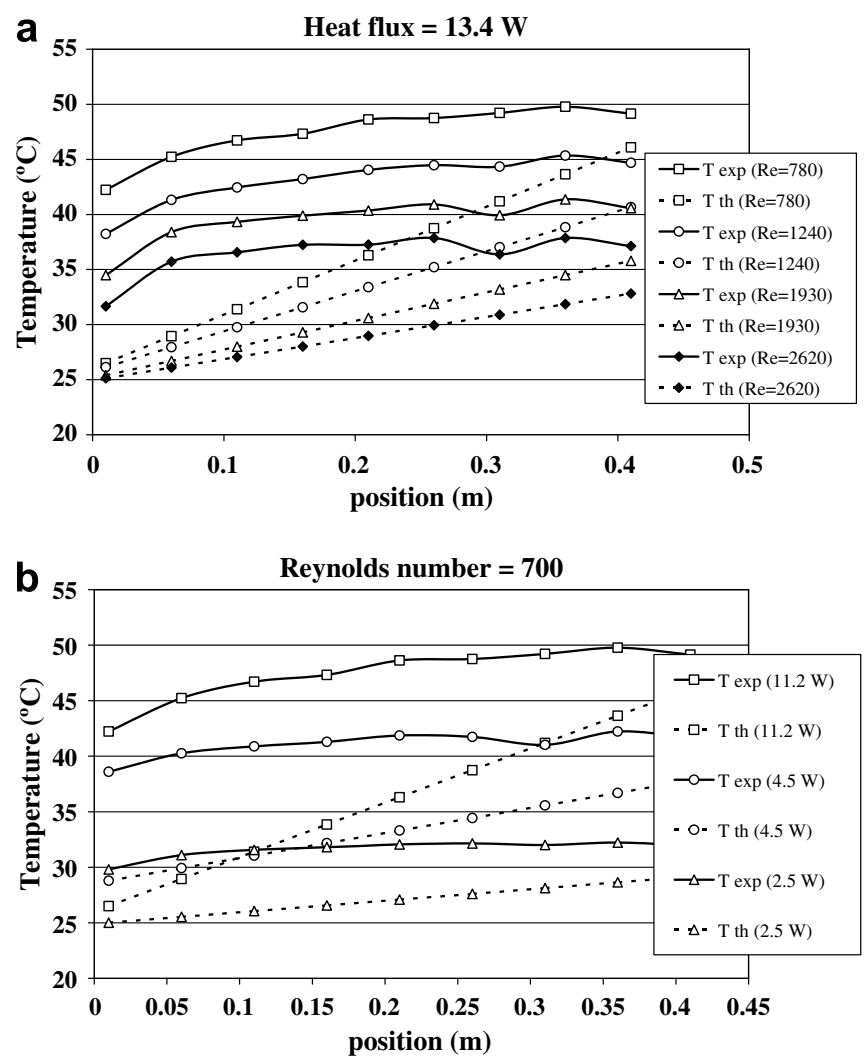

Fig. 7. Measured temperature profiles for different Reynolds number (a) and heat flux (b). The dotted lines represent the temperature profile which would be observed with a constant heat flux.

core of the fluid. In experiments where the local heat flux remains constant all along the channel, $T_{\mathrm{w}}$ and $T_{\mathrm{f}}$ are linear functions of $z$ and the temperature difference $T_{\mathrm{w}}-T_{\mathrm{f}}$ remains constant except at the channel entrance where boundary layers form. Fig. 7 shows the axial evolution of the temperatures recorded by the nine thermocouples together with what they would be for a homogeneous heat flux feeding. In Fig. 7(a), the electric power has been main- tained constant whereas the Reynolds number has been varied. In Fig. 7(b), the Reynolds number remains equal to 700 but the electric power varies from 2 to $11 \mathrm{~W}$.

In both figures, it is clear that the experimental temperature profiles are far from being linear. Calculating the value of the parameter $M$ introduced by Maranzana et al. [9] gives $M=0.57$ which shows that longitudinal conduction along the aluminium plate and the transfer by convection are of the same order of magnitude. This explains the temperature behaviour.

A simulation with the FLUENT software has been made to check these results (cf. Fig. 8). Half the device is represented to reduce the size of the mesh (equal to 243000 elements). Fig. 9 represents numerical temperature profiles and experimental measurements for a Reynolds number equal to 1425 and an electric heating power equal to $11 \mathrm{~W}$ corresponding to a mean heat flux density equal to $6400 \mathrm{~W} / \mathrm{m}^{2}$.

The computation confirms that the fluid temperature is not linear. We also see that the temperatures given by the thermocouples are an intermediate value between the

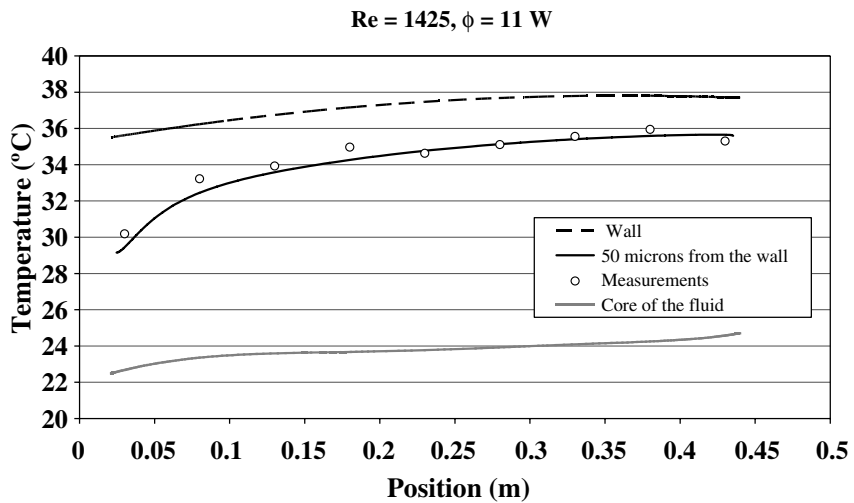

Fig. 9. Comparison between measured and computed temperature profiles at different locations (wall interface, $50 \mathrm{~mm}$ from the wall, in the middle of the channel).

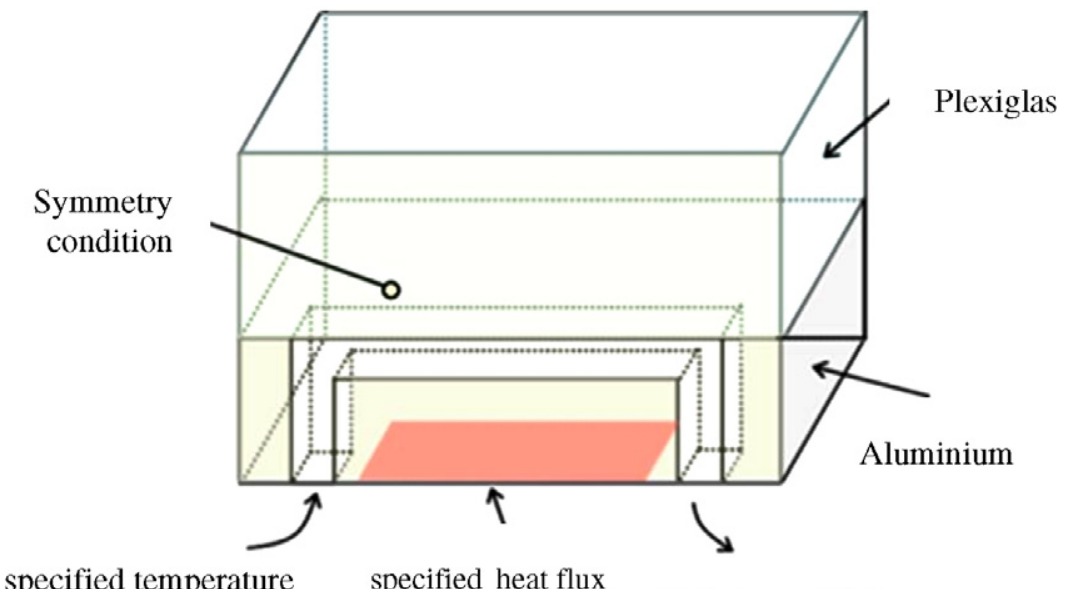

Inlet: specified temperature specified heat flux and flow rate

Outlet: specified pressure

Fig. 8. Geometry and boundary conditions introduced in the numerical simulation. 

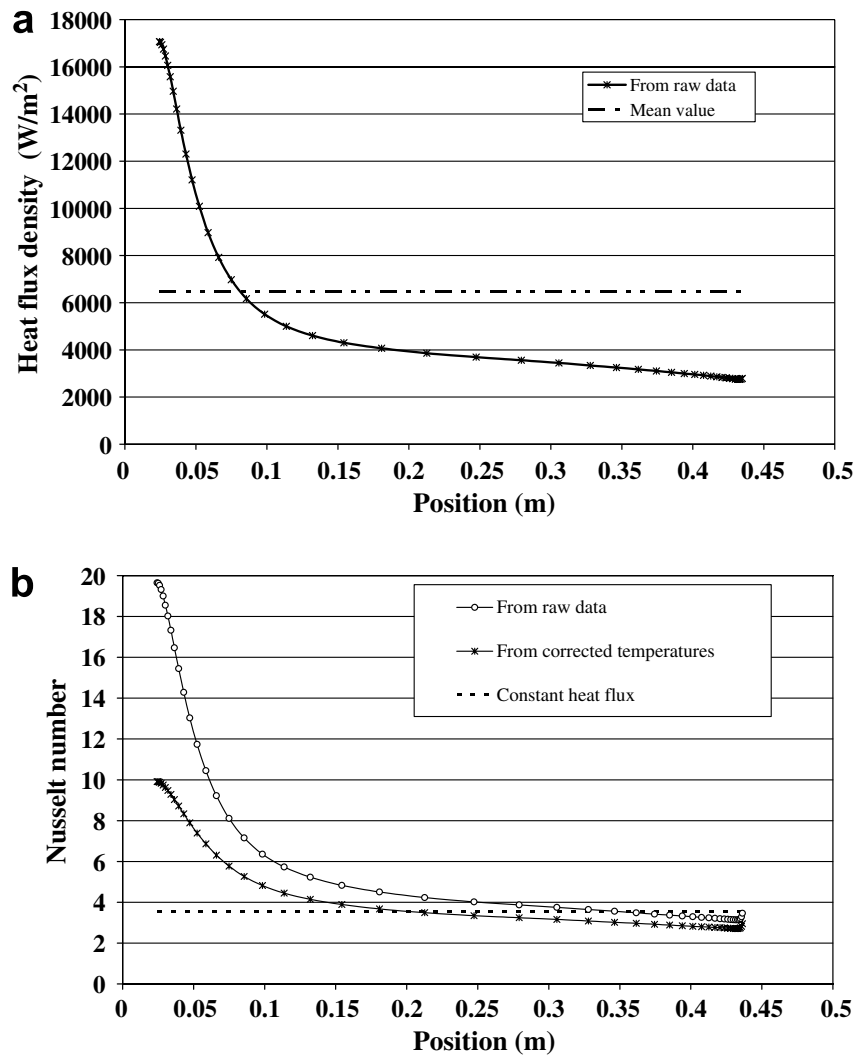

Fig. 10. Heat flux (a) and Nusselt number (b) evolution in the test section (raw data correspond to the thermocouples measurements, i.e. $T_{\text {wexp }} \mathrm{cf}$. Eq. (5)).

interface temperature and the core temperature. It was actually shown that our data fit well with the temperature profile at a distance $\delta$ equal to $50 \mu \mathrm{m}$ from the wall. This result shows that inserting thermocouples at the wall-fluid interface actually gives a value which should be corrected to obtain the exact wall temperature.

The numerical heat flux distribution is represented in Fig. 10(a) which shows its non-uniform evolution all along the test section. Fig. 10(b) shows the calculated Nusselt number distribution. In the first calculated value, the Nusselt number is computed with the temperature of the thermocouples. As we know that the thermocouples measure the temperature of the fluid at a distance $\delta$ equal to $50 \mu \mathrm{m}$, the data from the thermocouples should be corrected as follows to obtain the exact wall temperature:

$T_{\mathrm{w}}=T_{\mathrm{wexp}}(z)+\frac{\varphi(z) \delta}{\lambda}$

with $T_{\text {wexp }}$ being the thermocouples measurement value, $\varphi$ he local heat flux density and $\lambda$ the fluid thermal conductivity. Thus, the Nusselt number shape is not modified but the calculated value is improved. Doing so, experimental conditions of this study prove that thermal regime is not established in the test section. The thermal length is expressed as following [13]:

$L_{\mathrm{t}}=0.05 D_{\mathrm{h}} \operatorname{Re} P r$ and this length varies from 0.113 to $2.83 \mathrm{~m}$ in the test section, when Reynolds varies from 310 to 7780 .

Moreover, the Nusselt number value at the end of the test section does not converge to an asymptote value. This phenomenon proves that both the heat flux redistribution in the wall and the thermal entry length in the test section give the Nusselt evolution.

\section{Conclusion}

Experimental friction factor results show a good agreement with classical correlations for conventional channels. Heat transfer results show that experimental temperatures correspond exactly to a calculated temperature situated at $50 \mu \mathrm{m}$ from the wall. Thus, this study indicates that no unexplained physical phenomena seem to appear in a $1 \mathrm{~mm}$ channel. However, the difficulty to measure fluid temperature and particularly the thermocouple intrusion limit is clearly emphasized. Moreover, some precautions have to be taken to control heat flux homogeneity.

\section{References}

[1] B. Agostini, Etude expérimentale de l'ébullition de fluide réfrigérant en convection forcée dans des mini-canaux, Thèse Université Joseph Fourier, Grenoble I, 2002.

[2] R. Bavière, S. Le Person, F. Ayela, M. Favre-Marinet, An experimental study of water flow in smooth and rectangular micro-channels, in: S.G. Kandlikar (Ed.), Proc. 2nd Int. Conf. Microchannels and Minichannels, Rochester, New York, USA, ASME, 2004.

[3] H. Blasius, Grenzschichten in flüssigkeiten mit kleiner Reibung, Z. Math. Phys. 56 (1908).

[4] D. Brutin, Ecoulements liquides en microtubes et ébullition convective en minicanaux: étude expérimentale et modèlisation. Thèse de l'université de provence Aix-Marseille I, 2003.

[5] S.B. Choi, R.F. Barron, R.O. Warrington, Fluid flow and heat transfer in microtubes, Proc. ASME DSC 32 (1991) 123-134.

[6] P. Gao, S. Le Person, M. Favre-Marinet, Scale effects on hydrodynamics and heat transfer in two-dimensional mini and microchannels, Int. J. Therm. Sci. 41 (2002) 1017-1027.

[7] X.N. Jiang, Z.Y. Zhou, J. Yao, Y. Li, X.Y. Ye, Micro-fluid flow in microchannel, in: Proc. Transducers 95, Stockholm, Sweden, vol. 25 29, 1995, pp. 317-320.

[8] S. Kandlikar, W. Grande, Evolution of microchannel flow passages thermohydraulic performance and fabrication technology, Heat Transfer Eng. 25 (2003) 3-17.

[9] G. Maranzana, I. Perry, D. Maillet, Mini- and micro-channels: influence of axial conduction in the walls, Int. J. Heat Mass Transfer 47 (2004) 3993-4004.

[10] I. Papautsky, J. Brazzle, T. Ameel, A.B. Frazier, Laminar fluid behaviour in microchannels using micropolar fluid theory, Sens. Actuators 73 (1-2) (1999) 101-108.

[11] J. Pfahler, J. Harley, H. Bau, J. Zemel, Gas and liquid flow in small channels, Proc. SME Micromech. Sensors, Actuators, Systems, DSC 32 (1991) 49-60.

[12] D. Phares, G. Smedley, A study of laminar flow of polar liquids through circular microtubes, Phys. Fluids 16 (2004) 1267-1272.

[13] R. Shah, A. London, Laminar flow forced convection in ducts, Advances in Heat Transfer, Academic Press, 1978.

[14] P. Wilding, M.A. Shoffner, L.J. Kircka, Manipulation and flow of biological fluids in straight channels micromachined in silicon, Clin. Chem. 40 (1994) 43-47. 
[15] P. Wu, W.A. Little, Measurement of friction factors for the flow of gases in very fine channels used for microminiature Joule-Thomson refrigerators, Cryogenics 5 (1983) 273-277.
[16] D. Yu, R. Warrington, R. Barron, T. Ameel, An experimental and theoretical investigation of fluid flow and heat transfer in microtubes, in: Proc. 4th ASME JSME Thermal Engineering Joint Conf., 1995. 